\title{
Dental caries prevention strategies among children and adolescents with immigrant - or low socioeconomic backgrounds- do they work? A systematic review
}

\author{
Marit S. Skeie ${ }^{1 *}$ and Kristin S. Klock ${ }^{2^{*}}$
}

\begin{abstract}
Background: This systematic review was designed to uncover the most reliable evidence about the effects of caries preventive strategies in children and adolescents of immigrant or low socioeconomic backgrounds.

Methods: According to pre-determined inclusion and exclusion criteria, relevant articles focusing on underprivileged groups were electronically selected between January1995 and October 2015. The literature search was conducted in five databases; PubMed, Embase, CINAHL, SweMed+ and Cochrane Library. Accepted languages for included articles were English, German and Scandinavian languages. Abstracts and selected articles in full text were read and assessed independently by two review authors. Systematic reviews and meta-analyses were not included. Also articles with topics of water fluoridation and fluoride toothpaste were excluded, this due to all existing evidence of anti-caries effect for disadvantaged groups. The key data about the main characteristics of the study were compiled in tables and a quality grading was performed.

Results: Thirty-seven articles were selected for further evaluation. Supervised toothbrushing for 5-year-old school children was found to be an effective prevention technique for use in underprivileged groups. Also a child/mother approach, targeting nutrition and broad oral health education of mothers showed effectiveness. For older children, a slow-release fluoride device and application of acidulated phosphate fluoride (APF) gel showed to be effective.

Conclusion: On the basis of this review, we maintain that in addition to studies of water fluoridation and fluoride toothpaste, there are other preventive intervention studies providing scientific evidence for caries reduction among children and adolescents with immigrant or low socioeconomic backgrounds.
\end{abstract}

Keywords: Dental caries, Socioeconomy, Children, Immigrants, Prevention, Systematic literature review

\section{Background}

Dental caries is a disease with modifiable risk factors that during recent decades has been shown to have a skewed distribution in both the industrialized and the non-industrialized world. Those most heavily affected are usually found in vulnerable population groups as among people with low income, in some immigrant minorities and where these two populations overlap [1].

\footnotetext{
* Correspondence: marit.skeie@uib.no; kristin.klock@uib.no

${ }^{1}$ Department of Clinical Dentistry, Pediatric Dentistry, The Faculty of Medicine, University of Bergen, Aarstadveien 19, N-5009 Bergen, Norway 2Department of Clinical Dentistry, Community Dentistry, The Faculty of Medicine, University of Bergen, Aarstadveien 19, N-5009 Bergen, Norway
}

This information is today so widely accepted that Early Childhood Caries (ECC) is used as a marker of social inequality [2]. Furthermore, the general caries decline, documented among children and adolescents, has mostly benefitted the general population and has been shown to be limited in peers from low-income households or from ethnic minority groups [3-7].

Epidemiological studies from the Scandinavian countries (Denmark, Sweden and Norway) have revealed disparities in caries between children and adolescents with and without foreign backgrounds [8-10] and concluded a worse caries status among those with immigrant background, this in accordance with recent findings from 
USA [11]. Among caries determinants, not only low income, but also socio- cultural conditions that influence their lives, play important roles [8]. To strength their identity, it is not unusual that unfavorable types of diet and dietary patterns from country of origin are maintained in its traditional way [12].

Different theoretical explanations for inequality in oral health have been discussed and presented in a literature review by Sisson in 2007 [13]. According this author, future research should focus more on how people live their lives in different social classes and how background social factors influence lifestyle decisions [13]. Lack of understanding of individuals in their social context, how they live their lives, may be one of the multi-faceted reasons why traditional caries prevention programs have not succeeded in disadvantaged groups. It is understandable that prevention of oral diseases is not given the highest priority under challenging living circumstances. Young people living in vulnerable population groups tend to have parents with low educational backgrounds, which entails a higher risk of having negative attitudes concerning their children's oral health related behaviours [14]. Having diets with high sugar content and suboptimal tooth brushing habits are associated with some immigrant subgroups $[15,16]$ and with materially deprived neighbourhoods [17]. For the poorest families, the cost of toothbrushes and toothpaste may represent a potential barrier to regular toothbrushing [18]. In some countries, lack of available and accessible regular dental care constitutes a barrier and, especially in those countries, the children who need dental care the most are the ones least likely to visit a dental clinic [19].

Difficulty reducing disparities in oral health is a matter of concern for researchers worldwide [20]. Traditional interventions are criticized for lacking or not sufficiently considering the socio-economic context [21] or, additionally, the oral health impact of acculturation [22]. Adjustment of established preventive strategies or formation of new ones are needed [23, 24] which, in focusing on living conditions and lifestyles, should combine social policy and individual actions [20]. In spite of this, traditional interventions with wide-ranging approaches, still play their roles in reducing oral health inequalities, as all individuals share many risk factors [25].

Caries is a largely preventable disease. In order to reach the goal of reducing oral health inequalities $[19,26]$, it is essential to search for scientific evidence for effectiveness in preventive programs targeting disadvantaged and socially marginalized groups. These groups have a history of not benefitting from traditional preventive interventions [27]. However, to our knowledge, there are few literature reviews concerning a caries preventive intervention approach to children and adolescents from subgroups of immigrant populations or from low socioeconomic backgrounds. For this reason, the aim of this systematical review is to uncover the most reliable evidence about the effects of caries preventive strategies in children and adolescents of immigrant or low socioeconomic backgrounds. The research question we wish to answer is: "Do preventive strategy studies exist that offer scientific evidence for caries reduction among children and adolescents with immigrant or low socioeconomic backgrounds?"

\section{Methods}

On March 2nd 2015, a systematic electronic literature search was conducted in five databases; PubMed, Embase, CINAHL, SweMed+ and Cochrane Library. Articles were also identified through hand searches in the reference lists of already selected articles. Totally, 1804 abstracts were identified. An updated search was undertaken 10 Oct the same year, but no other articles were found or included in the final list. Table 1 shows the search equation applied in terms of $\mathrm{MeSH}$ terms and search words for each database.

The search was limited to peer-reviewed articles and it did not allow systematic reviews nor meta-analyses to be included. Only articles published during the period January1995 - October 2015 were included. Accepted languages for included articles were English, German, Norwegian, Swedish or Danish. Non-randomized studies were accepted. Grey literature was excluded as this type of literature can vary considerably in standard of quality, review and production. Otherwise, the search algorithm included many ways of grouping socio-demographiceconomic backgrounds, therefore different models for this were revealed in the articles; education or profession of the parents or caregivers, socially deprived or low income communities, child's home post code, assigned as a Carstairs socio-economic deprivation score and others scores such as the Jarman underprivileged Area score, Townsend index and the ABIPEME index. The term "Underprivileged group" was used to cover all aspects used in the articles, but articles based on populations from explicit indigenous or tribe groups were excluded. The studies described in the articles were divided into national, subnational (from regions) and community (cities or small areas) levels.

Studies with a clear outcome measure like caries experience or caries prevalence were included, but not studies comparing different caries interventions without a control group. Interventions were denoted as effective when statistically significant differences in dental caries status could be documented between intervention- and control groups. In cases where other outcome measures together with caries experience were investigated, these measures were not included as outcomes in the tables and their results were also not reported. 


\section{Table 1}

\begin{tabular}{|c|c|}
\hline \multicolumn{2}{|l|}{ PubMed } \\
\hline \multicolumn{2}{|c|}{$\begin{array}{l}\text { The free text in PubMed translated and combined with MeSH-terms } \\
\text { (Medical Subjects Headings (MeSH): } \\
\text { (patient education OR health education dental OR prevention OR } \\
\text { promotion OR motivation OR motivating interview OR Program } \\
\text { evaluation OR Dental care for children) AND (immigrant OR immigrants } \\
\text { OR refugee OR refugees OR socioeconomic factors OR vulnerable OR } \\
\text { Indigent OR indigency OR poverty) AND dental caries AND (child OR } \\
\text { children) }\end{array}$} \\
\hline \multicolumn{2}{|l|}{ EMBASE } \\
\hline \multicolumn{2}{|c|}{$\begin{array}{l}\text { ((patient education or health education dental or prevention or } \\
\text { promotion or motivation or motivating interview or Program } \\
\text { evaluation or Dental care for children) and (immigrant or immigrants } \\
\text { or refugee or refugees or socioeconomic factors or vulnerable or } \\
\text { Indigent or indigency or poverty) and dental caries and (child or } \\
\text { children)).mp. } \\
\text { Explanation for searching fields: } \\
\text { [mp = title, abstract, heading word, drug trade name, original title, } \\
\text { device manufacturer, drug manufacturer, device trade name, keyword] }\end{array}$} \\
\hline \multicolumn{2}{|l|}{ Cinahl } \\
\hline \multicolumn{2}{|c|}{$\begin{array}{l}\text { ((patient education or health education dental or prevention or promotion } \\
\text { or motivation or motivating interview or Program evaluation or Dental } \\
\text { care for children) and (immigrant or immigrants or refugee or refugees or } \\
\text { socioeconomic factors or vulnerable or Indigent or indigency or poverty) } \\
\text { and dental caries and (child or children)) }\end{array}$} \\
\hline \multicolumn{2}{|l|}{ SweMed+ } \\
\hline \multicolumn{2}{|c|}{ Search with MeSH-terms. } \\
\hline Search no. & Search words \\
\hline 1 & exp: "dental caries" \\
\hline 3 & exp: "socioeconomic factors" \\
\hline 8 & exp: "emmigrants and immigrants" \\
\hline 10 & \#3 OR \#8 \\
\hline 13 & exp: "Infant" OR "child" OR "adolescent" \\
\hline 14 & $\# 1$ AND \#10 AND \#13 \\
\hline \multicolumn{2}{|l|}{ Cochrane } \\
\hline ID & Search \\
\hline$\# 1$ & MeSH descriptor: [Dental Caries] explode all trees \\
\hline \#2 & Caries \\
\hline \#3 & MeSH descriptor: [Socioeconomic Factors] explode all trees \\
\hline \#4 & migrant* or immigrant* or refugee* \\
\hline \#5 & child or children \\
\hline \#6 & $\# 1$ or \#2 \\
\hline \#7 & \#3 or \#4 \\
\hline \#8 & $\# 5$ and \#6 and \#7 \\
\hline
\end{tabular}

The different steps of a PRISMA [28] (Fig. 1) were used as a platform when performing the systematic literature review (identification, screening, eligibility, inclusion). The identification consisted of three levels in which inclusion and exclusion criteria were followed: 1 ) title and authors, 2) abstract and 3) full text. During the whole searching process until the final results, the same two review authors (MSS, KSK) independently read and evaluated the articles. Printed articles were only read when abstracts were determined to be of relevance and within the scope of the present systematic review. Later, both review authors independently did the assessment before deciding to include the article into the final review. If, for example, only one author found the abstract potentially relevant, but the other did not, full-text articles were read by both. In case of further disagreement, extra time to discuss was used until a consensus was reached. As both authors agreed on the selection, a consensus was not necessary. The articles not included did not undergo further analysis. Altogether, 37 articles were selected. As both water fluoridation [29, 30] and fluoride toothpaste [31, 32] for years have presented evidence that they provide anti-caries benefit for disadvantaged groups, it was seen upon as superfluous and unnecessary for further evaluation in this literature review.

The PICOS approach was followed to give the reader the key information (participants, interventions, comparators, and study design). These central themes and topics were extracted from the included articles and presented in tables. The Hierarchy of research design of the U.S. Preventive Services Task Forces (USPSTF) [33] was used to grade the level of quality of evidence (Table 2), but additional information was added about sample size, randomization, caries examination calibration, number of examiners, radiographic examination, blinding and outcome measures. Evidence based on randomized controlled trials begins as high quality evidence, but the confidence in evidence gradually diminished for several reasons, including:1) study limitations; 2) inconsistency of results; 3) indirectness of evidence; 4) imprecision; and 5) reporting bias [34]. The final discussion, summarizing the evidence for effectiveness, included only randomized study designs. To define age distribution of various studies, the studies were categorized to either belong to Age group I: mother/baby approach/preschool children at baseline ( $\leq 5$-yr-olds), or Age group II: schoolchildren and adolescents.

\section{Results}

Thirty-seven articles were selected for further evaluation. The key data about the main characteristic of the studies are compiled in Table 3. A wide range of intervention domains were presented; "Other fluoride supplements" $(n=9)$, "Oral health studies and programs including fluoride supplements with other intervention types" $(n=13)$, "Sealants" $(n=3)$, "Supervised toothbrushing" $(n=3)$, "Nutrition" $(\mathrm{n}=3)$, "Motivating interviewing" $(n=1)$, "Oral health education" $(n=4)$ and "Remineralizing paste" $(n=1)$. Different countries were represented in the extracted publications, but the majority $(n=24)$ originated from European countries, especially from Great Britain. Fewer articles were published 


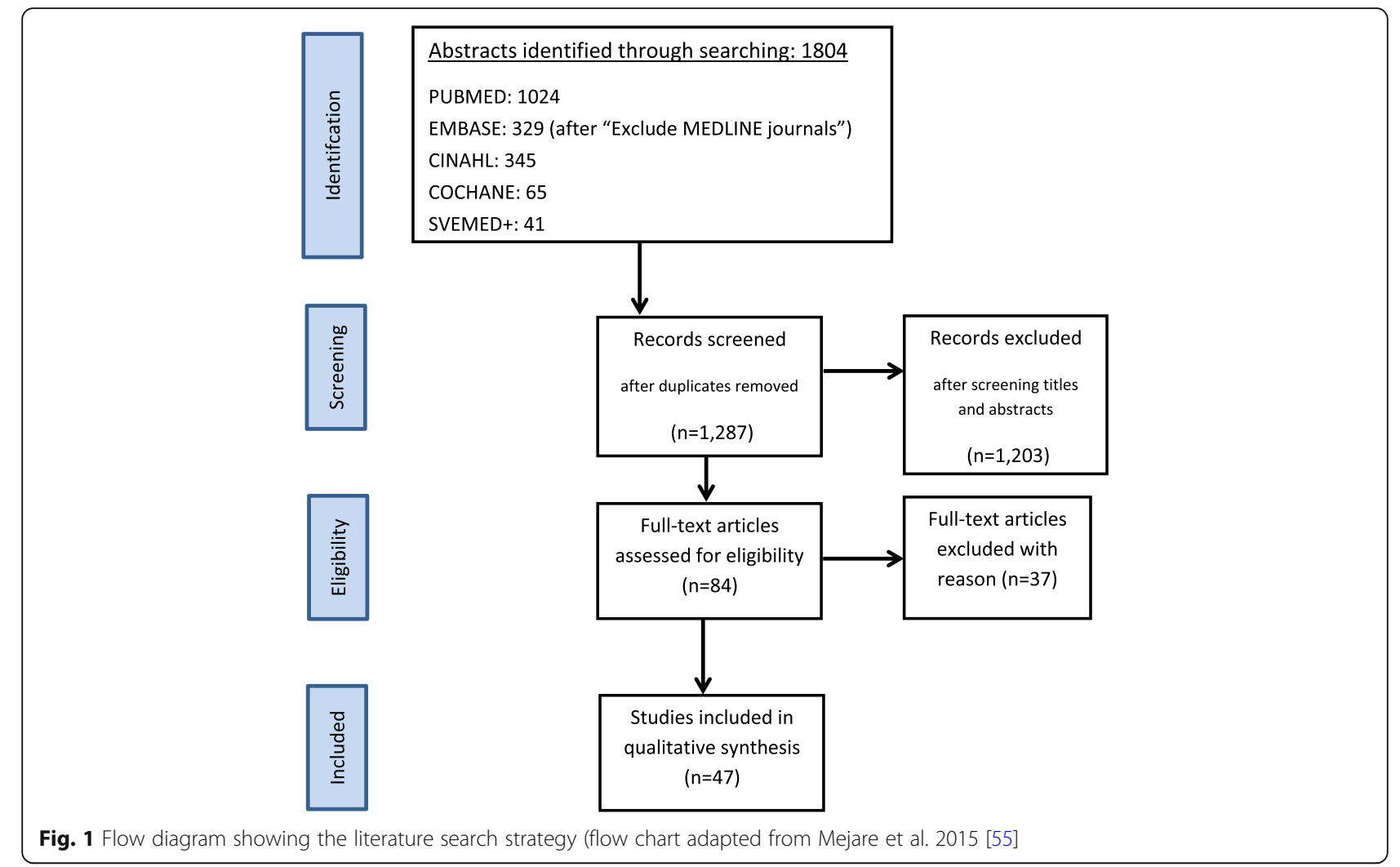

before 2009 than more recently, in 2009 and after $(16$ vs19 articles).

Table 4 is a quality rating of the different studies including topics such as sample size, randomization, caries examination calibration, number of oral examiners, use of radiographic technologies, blinding, length of intervention period and type of outcome measurement. The overall judgement of the quality of evidence showed that few studies $(n=3)$ used radiographic bitewings. Only six studies explicitly reported that they included enamel caries in the caries examination. Table 5, based on the USPSTF evidence classification and modified by Tutak $M$ et al. [35], illustrates that the intervention target age groups differed; 19 studies belonged to Age group I and 18 studies to Age group II. Articles categorized separately as Level of evidence I (from properly designed randomized control trial) were confined both to Age group I $(n=8)$ and Age group II $(n=6)$. Four studies of the originally Level of evidence I studies provided evidence of caries reduction in Age group I. The domains were "Nutritional program" in a mother and child approach $(n=1)$ [36], "Oral health educational intervention program" $(\mathrm{n}=1)$ [37] and "Supervised toothbrushing" $(n=2)[38,39]$. The sample sizes of the two last mentioned studies were pooled, resulting in a sample size of 831 (completing the trial: test = 420 , controls $=411$ ).

As for Age group II, five Level of evidence I studies reported having a caries reducing effect [40-44], though the intervention used by Agrawal et al. [40] showed effectiveness restricted to incipient lesions. The domains were "Other fluoride supplement" $(n=$ 2 ) and "Oral health studies and programs including fluoride supplements with other intervention types" $(n=3)$.

Table 2 Quality of evidence according to assessment system of the US Preventive Services Task Force, from Grimes and Schulz [33]

I Evidence from at least one properly designed randomized control trial

II-1 Evidence obtained from well-designed controlled trials without randomization

II-2 Evidence from well-designed cohort or case-control studies, preferably from more than one centre or research group

II-3 Evidence from multiple time series with and without the intervention. Important results in uncontrolled experiments (such as introduction of penicillin treatment in the 1940s) could also be considered as this type of evidence

III Opinions of respected authorities, based on clinical experience, descriptive studies, or reports of expert committees 
Table 3 Studies' characteristics $(n=37)$. Studies focusing on water fluoridation and fluoride toothpaste are not included

\begin{tabular}{|c|c|c|c|c|}
\hline \# Study & $\begin{array}{l}\text { Country } \\
\text { Level }\end{array}$ & $\begin{array}{l}\text { Age groups } \\
\text { (yrs) }\end{array}$ & $\begin{array}{l}\text { Follow - up/retrospective } \\
\text { period }\end{array}$ & Intervention \\
\hline \multicolumn{5}{|l|}{ Other fluoride supplement $(n=9)$} \\
\hline 1. Agrawal N \& Pushpanjali K. 2011 [40] & $\begin{array}{l}\text { India } \\
\text { Community }\end{array}$ & $9-16$ & Follow-up: 6/12 mo. & $\begin{array}{l}\text { Acidulated phosphate fluoride } \\
\text { (APF) gel }\end{array}$ \\
\hline 2. Meyer-Lueckel H et al. 2010 [56] & $\begin{array}{l}\text { Germany } \\
\text { Community }\end{array}$ & $6-9$ & Retrospective period: $2-4$ yrs. & Fluoride tablets \\
\hline 3. Oliveira BH et al. 2014 [57] & $\begin{array}{l}\text { Brazil } \\
\text { Community }\end{array}$ & $1-4$ & Follow up: 2 yrs. & Fluoride Varnish \\
\hline 4. Pitchika V et al. 2013 [58] & $\begin{array}{l}\text { Germany } \\
\text { Subnational }\end{array}$ & $2-3$ & Follow-up: 2 yrs. & Fluoride Varnish \\
\hline 5. Schuller AA \& Kalsbeek H. 2003 [59] & $\begin{array}{l}\text { The Netherlands } \\
\text { Subnational }\end{array}$ & $15-17$ & Cross-sectional comparisons & Topical fluoride \\
\hline 6. Riley JC et al. 2005 [60] & $\begin{array}{l}\text { United Kingdom } \\
\text { Subnational }\end{array}$ & Mean age: 10-11 & Cross-sectional comparisons & Milk fluoridation \\
\hline 7. Levin KA et al. 2009 [61] & $\begin{array}{l}\text { United Kingdom } \\
\text { Subnational }\end{array}$ & Mean age: 11.39 & Cross-sectional comparisons & Fluoride rinsing \\
\hline 8. Toumba KJ \& Curzon ME. 2005 [41] & $\begin{array}{l}\text { United Kingdom } \\
\text { Community }\end{array}$ & 8 & Follow up: 2 yrs & Slow-releasing fluoride device \\
\hline 9. Wennhall I et al. 2014 [62] & $\begin{array}{l}\text { Sweden } \\
\text { Community }\end{array}$ & $12-14$ & Follow up: 2 yrs & Fluoridated salt \\
\hline
\end{tabular}

Oral health studies and programs including fluoride supplements with other intervention types $(n=13)$

$\begin{array}{lll}\text { 10. Minah G et al. } 2008 \text { [63] } & \text { USA } & \text { Community }\end{array}$

11. Bravo et al. $1997[42]$

12. Songpaisan $Y$ et al. $1995[64]$

13. Wennhall I et al. 2008 [65]

14. Wagner $Y$ et al. 2014 [66]

15. Dülgergil CT et al. 2005 [67]

16. Meurman P et al. 2009 [68]

17. Armfield JM \& Spencer AJ. 2007 [43]

18. Blair $Y$ et al. 2004 [69]

19. Blair $Y$ et al. 2006 [70]

20. Stokes E et al. 2011 [44]

21. Lindgard M 2013 [71]

\section{Spain \\ Community}

Thailand

Community

Sweden

Subnational

Austria

Subnational

Turkey

Community

Finland

Community

Australia Subnational

Scotland

Community

Scotland

Community

5

Great Britain

Community

Sweden

Community

2

\section{6-8}

$7-8,12-13$

New mothers at time after birth

10-11

$18 \mathrm{mo}$

Mean age: $10.5 \quad$ Follow-up: mean of 2 yrs

36-59 mo

Follow-up: 2 yrs., 4 yrs

Follow-up: 6 yrs.

Secondary analysis of routine caries datasets 1997-98 to 2003-04

Follow-up: 2 yrs.

Retrospective evaluation of Promoting Program - children

Follow up: 6 mo, 1 yr

Follow up: 5-yrs.

13

Follow-up: 1 yr.
For high caries risk subjects with caries experience and high MS units: fluoride varnish and reinforcement of caries prevention

Sealant and Fluoride Varnish

Gl cement/sealants/HF application

Parent education/ toothbrushing instruction/ diet/fluoride tablets

Oral hygiene instructions for mother/child (MI approach)

ART in combination with Fluoride Varnish fissure sealants

For families for MS-positive children: Health education to caretakers/ xylitol lozenges for the child.

Fissure sealants in combination with water fluoridation

Community based oral health program; nutrition, oral hygiene, fluoride dentifrice, outreach activity

Community based oral health program

Supervised toothbrushing/ self-applied high-fluoride gel by toothbrushing 
Table 3 Studies' characteristics ( $n=37$ ). Studies focusing on water fluoridation and fluoride toothpaste are not included (Continued)

\begin{tabular}{|c|c|c|c|c|}
\hline \# Study & $\begin{array}{l}\text { Country } \\
\text { Level }\end{array}$ & $\begin{array}{l}\text { Age groups } \\
\text { (yrs) }\end{array}$ & $\begin{array}{l}\text { Follow - up/retrospective } \\
\text { period }\end{array}$ & Intervention \\
\hline & & & & $\begin{array}{l}\text { Prevention program-oral } \\
\text { information, diet and hygiene } \\
\text { counseling, fluoride tablets }\end{array}$ \\
\hline 22. Baca P et al. 2004 [72] & $\begin{array}{l}\text { Spain } \\
\text { Community }\end{array}$ & $6-7$ & Follow-up: 24 mo & $\begin{array}{l}\text { Clorhexidine in combination } \\
\text { with Thymol Varnish }\end{array}$ \\
\hline \multicolumn{5}{|l|}{ Sealants $(n=3)$} \\
\hline 23. Muller-Bolla M et al. 2013 [73] & $\begin{array}{l}\text { France } \\
\text { Community }\end{array}$ & $6-7$ & Follow-up: 1 yr. & Resin-based sealant \\
\hline 24. Tickle M et al. 2007 [74] & $\begin{array}{l}\text { England } \\
\text { Subnational }\end{array}$ & $5-14$ & $\begin{array}{l}\text { Retrospective period: data } \\
\text { collected from patients' case } \\
\text { notes }\end{array}$ & Fissure sealant \\
\hline 25. Baldini V et al. 2010 [75] & $\begin{array}{l}\text { Portugal } \\
\text { Sub- national }\end{array}$ & 8 & $\begin{array}{l}\text { Retrospective period: } 2 \text { yrs. } \\
\text { (assessed when } 10 \text { yrs) }\end{array}$ & Sealant \\
\hline \multicolumn{5}{|l|}{ Toothbrushing $(n=3)$} \\
\hline 26. Curnow MM et al. 2002 [38] & $\begin{array}{l}\text { Scotland } \\
\text { Subnational }\end{array}$ & Mean age 5.3 . & Follow-up: 2 yrs & Supervised toothbrushing \\
\hline 27. Jackson RJ et al. 2005 [39] & $\begin{array}{l}\text { England } \\
\text { Community }\end{array}$ & Mean age: 5.63 & Follow-up: at 21 mo & Supervised toothbrushing \\
\hline 28. Macpherson LMD et al. 2013 [52] & $\begin{array}{l}\text { Scotland } \\
\text { National }\end{array}$ & 5 & $\begin{array}{l}\text { Population study involving } \\
\text { multiple cross-sectional dental } \\
\text { epidemiology surveys }\end{array}$ & Supervised toothbrushing \\
\hline \multicolumn{5}{|l|}{ Nutrition $(n=3)$} \\
\hline 29. Freeman R et al. 2001 [76] & $\begin{array}{l}\text { Ireland } \\
\text { Subnational }\end{array}$ & 9 & Follow-up: 1 yr., 2 yrs & Healthier eating (BBB) \\
\hline 30. Feldens CA et al. 2010 [36] & $\begin{array}{l}\text { Brazil } \\
\text { Community }\end{array}$ & $6,8,10,12 \mathrm{mo}$ & Follow-up: 4 yrs. & $\begin{array}{l}\text { Nutritional program (mother/ } \\
\text { child approach) }\end{array}$ \\
\hline 31. Chaffee BW et al. 2013 [77] & $\begin{array}{l}\text { Brazil } \\
\text { Community }\end{array}$ & $6 \mathrm{mo}$ & Follow-up:12 mo, 36 mo & $\begin{array}{l}\text { Nutritional training (mother/ } \\
\text { child approach) }\end{array}$ \\
\hline \multicolumn{5}{|l|}{ Motivating Interviewing $(n=1)$} \\
\hline 32. Ismail AL et al. 2011 [78] & $\begin{array}{l}\text { USA } \\
\text { Community }\end{array}$ & $0-5$ & Follow-up: 2 yrs. & $\begin{array}{l}\text { Tailored motivational } \\
\text { intervention (mother/child } \\
\text { approach) }\end{array}$ \\
\hline \multicolumn{5}{|l|}{ Oral health education $(n=4)$} \\
\hline 33. Kressin NR et al. 2009 [79] & $\begin{array}{l}\text { USA } \\
\text { Community }\end{array}$ & $6 \mathrm{mo}-5 \mathrm{yrs}$ & Follow-up & $\begin{array}{l}\text { For parents: } \\
\text { Communications skills training/ } \\
\text { EMR/educational brochure }\end{array}$ \\
\hline 34. Kowash MB et al. 2000 [80] & $\begin{array}{l}\text { United Kingdom } \\
\text { Community }\end{array}$ & $11.4 \mathrm{mo}$ & Follow-up: 3 yrs & $\begin{array}{l}\text { Oral health long term education } \\
\text { programme }\end{array}$ \\
\hline 35. Mohebbi SZ et al. 2009 [37] & $\begin{array}{l}\text { Iran } \\
\text { National }\end{array}$ & $\begin{array}{l}12-15 \text { mo with } \\
\text { mothers }\end{array}$ & Follow-up: 6 mo & Educational intervention \\
\hline $\begin{array}{l}\text { 36. van Palenstein Helderman } \\
\text { WH et al. } 1997 \text { [81] }\end{array}$ & $\begin{array}{l}\text { Tanzania } \\
\text { Community }\end{array}$ & $9-14$ yrs & Follow-up: 3,8,15 and 36 mo & $\begin{array}{l}\text { School-based OHE programme; } \\
\text { education and supervised } \\
\text { toohbrushing }\end{array}$ \\
\hline \multicolumn{5}{|l|}{ Remineralizing Paste $(n=1)$} \\
\hline 37. Plonka KA et al. 2013 [82] & $\begin{array}{l}\text { Australia } \\
\text { Subnational }\end{array}$ & $6 \mathrm{mo}$ & Follow-up: 12, 18, 24 mo & $\begin{array}{l}\text { Comparing a remineralizing } \\
\text { paste with and antibacterial } \\
\text { gel }\end{array}$ \\
\hline
\end{tabular}

\section{Discussion}

The present systematic review targeted high caries risk groups with a history of not benefitting from traditional preventive interventions [27]. As reducing the burden of oral disease in poor and marginalized populations is within the framework of the WHO Oral Health Programme [20], the need for such a systematic review should be evident enough. Khan et al. have stressed that the adjective systematic imply a lot; clearly formulated questions, identification of relevant studies, quality 


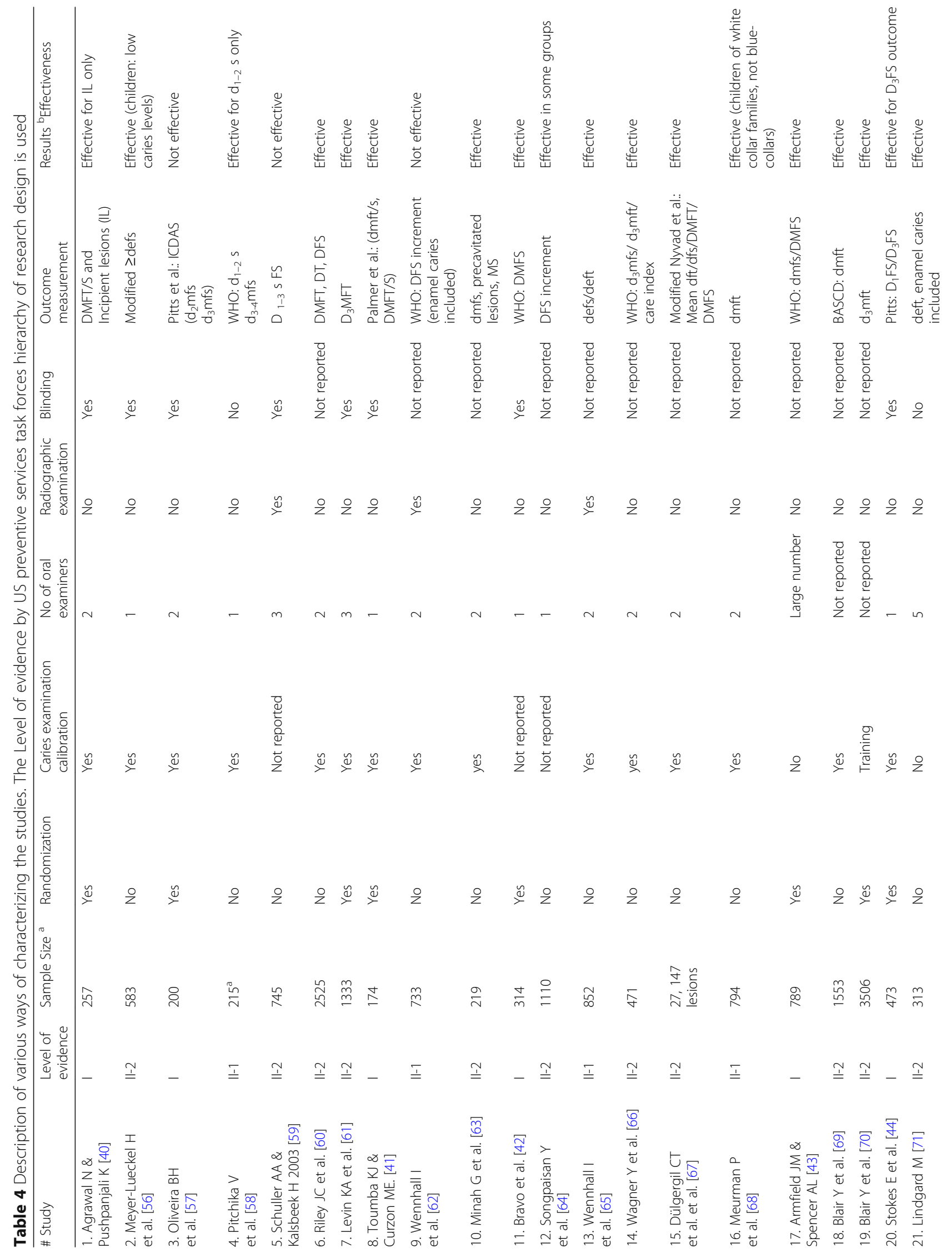




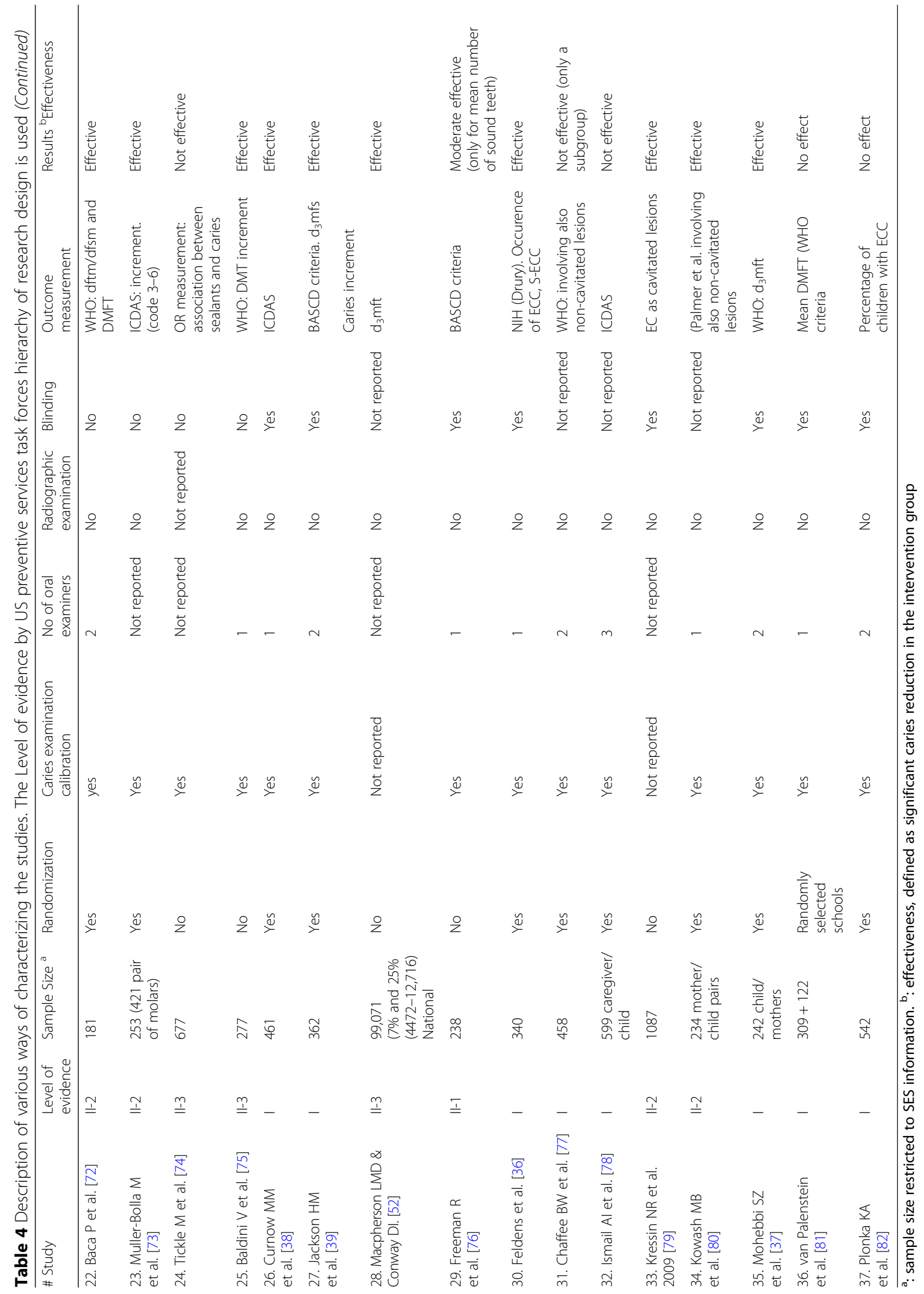


Table 5 A categorization of the articles based on the US Task Force evidence classification, modified by Tutak M et al. [35]

\begin{tabular}{|c|c|c|c|}
\hline US Task Force Level of evidence & Study design & No (\%) of published articles & Bibliography numbers \\
\hline \multicolumn{4}{|c|}{ Age group I. Mother/baby approach/pre-school children at baseline ( $\leq 5$-yr- olds) $(n=19)$} \\
\hline I: & Randomized controlled trials & $8(42 \%)$ & {$[36-39,57,77,78,82]$} \\
\hline II-1: & Controlled trials without randomization & $3(16 \%)$ & {$[58,65,68]$} \\
\hline II-2: & Cohort or case-controlled studies & $7(37 \%)$ & {$[63,66,69-71,79,80]$} \\
\hline II-3: & Case series & $1(5 \%)$ & {$[52]$} \\
\hline$\|$ & Case reports, Opinions of authorities & 0 & \\
\hline \multicolumn{4}{|c|}{ Age group II. Schoolchildren and adolescents $(n=18)$} \\
\hline I: & Randomized controlled trials & $6(33 \%)$ & {$[40-44,81]$} \\
\hline I-1: & Controlled trials without randomization & $2(11 \%)$ & {$[62,76]$} \\
\hline$\|-2:$ & Cohort or case-controlled studies & $8(45 \%)$ & {$[56,59-61,64,67,72,73]$} \\
\hline$\|-3$ & Case series & $2(11 \%)$ & {$[74,75]$} \\
\hline III & Case reports, opinions of authorities & 0 & \\
\hline
\end{tabular}

assessment and summarizes of the evidence by use of explicit methodology [45]. Also the present posed research question, "Do studies of preventive strategies exist that present scientific evidence for caries reduction among children and adolescents with immigrant or low socioeconomic backgrounds?", showed relevance, and should be described as both structured and explicit. According to Khan et al. the framing question fulfilled the requirements of Step 1 for conducting a systematic review. With respect to Khan et al., the present search based on five databases, though with some language restriction, to some extent fitted Step 2 of identifying relevant work.

This review was not the first to seek evidence of effectiveness for caries prevention. A recent review had an identical focus on ECC in the general child population [46], not restricted to underprivileged groups. The authors of another ECC review [47] concluded that their results reinforced the need for high quality clinical research conducted on different social and ethnic groups. Despite quality limitations in clinical research, reviews of evidence should continue to be undertaken, so that all selected studies should be subjected to as comprehensive, objective and attentive to quality assessment as possible.

To meet an evidence-based approach, the hierarchical grading system of USPSTF was used, but, due to its limitations referred in a paper of third USPSTF [33], this was not the only approach. In that paper it was claimed that a well-designed cohort study might be more compelling than an inadequately powered or poorly conducted randomized controlled trial. Randomized controlled trials have drawbacks too [48]. Due to this, in the present paper additional information was generated and presented in the different tables. Factors covered included the duration of the studies, sample sizes, calibration methods, number of examiners, blinding options, use of radiographic examination and outcome measurement according to caries diagnostic systems. This detailed quality overview should explore the heterogeneity of the included studies and thus permit a sufficiently critical evaluation.

The outcome, the effectiveness judged by caries reduction, must be analysed with caution due to its dependence on some underlying factors. One factor that showed heterogeneity was the outcome measurement. The dmtf/DMFT index was most often used, but whether enamel caries was included in the assessment varied. Another variation was the use of visual-tactile examination alone or the supplementary use of bitewing radiographs. Some studies also reported that caries diagnostic systems capable of diagnosing enamel lesions were used, but it was not always clearly explained whether enamel caries coding was used. Only three studies reported use of radiographs. This means that many studies not applying bitewing radiographs could have underscored proximal caries lesions [49]. Depending on the impact of these shortcomings of homogeneity, it was uncertain whether they had influenced the outcome effect or not, as the comparing groups (intervention and control groups) were both subjected to the same measurement methods. Furthermore, some studies had many examiners, which could have influenced the quality negatively. A previous systematic review of literature regarding methods for caries detection by Twetman et al. went as far as to exclude any trial with more than one examiner [50]. Some articles in the present review had a single or few examiners, but precise descriptions about how the caries calibration process had been conducted, important information [51], were often not described. However, also in these matters, what was most important was that the same examiners were responsible for caries registrations in both test and control groups.

The most evident finding from the present review was that those articles being classified as randomized controlled trials (Level I according to USPSTF) provided the best research evidence in other aspects like blinding, 
examiner calibration and number of examiners. Those articles that focused on oral health programs in which fluoride use constituted a component (domain: "Oral health studies and programs including fluoride supplements with other intervention types"), made it impossible to determine which intervention in the program was responsible for the effect. In Age group II, this problem affected three studies [42-44], leaving only two studies, those of Agrawal \& Pushpanjali [40] and of Toumba \& Curzon [41] for further evaluation (domain: "Other fluoride supplement"). The first study from India of Agrawal \& Pushpanjali [40] was a community intervention trial, conducted to assess the feasibility of an acidulated phosphate fluoride (APT) gel as a cariespreventive agent in a high-risk group of school children (9-16-year-old) with a low socio-economic background. The follow-up period was short (1 year), but it reported a caries reduction for the APF gel. This short time effect might be considered a strength of the study and supports the intervention type. The study of Toumba and Curzon [41] had as its objective to test a fluoridecontaining slow-released device in preventing dental caries in a group of low socio-economic schoolchildren from the age of 8 years during a 2-year-period. The authors concluded that the device attached to the buccal surface of the right maxillary first permanent molar, reduced caries incidence. As a consequence, the authors concluded that a fluoride-containing slow-released device showed promise as an preventive technique for use in schoolchildren and other priority groups.

Two studies in Age group I, targeting 5-year-olds, by Curnow et al. [38] and Jackson et al. [39], showed valid findings. Both studies focused on the efficacy of supervised fluoride toothbrushing, targeted into socially deprived areas. A pooling of participants was possible due to the homogeneity of the studies (age, follow-up period, in advance training for the persons in charge of the toothbrushing, a single calibrated caries examiner, examiner blinding), and this made the sample size substantial. Both studies could show to a significant reduction in dental caries. A national supervised toothbrushing program has also verified that this sort of preventive program shows caries reduction [52]. Although the data from these articles were derived from children who commenced their preventive activities as 5-year-olds, and not during the first two years of life, as suggested to be the most important age for effective interventions [53], cost-effectiveness could be expected to be better than for older individuals in Age group II.

Two other studies, shown to be effective in reducing ECC in the targeted populations, were the study of Feldens et al. [36] and that of of Mohebbi et al. [37], as they involved interventions during the first years of life. The intervention domains were "Nutrition" and "Oral health education" respectively and had a mother/child approach with baseline when the child was very young (six months in the first study and 12 months in the other). Both used trained non-dental staff, respectively undergraduate nutrition students and trained health staff at health centres. As feeding habits and sugar intake were given high priority in the oral health education study as well, the two studies had many features in common. The study of Mohebbi et al., [37] conducted in Iran, had the shortest follow-up period, only 6 - month-period, which reported in literature to be the shortest time period in primary dentition during which changes in caries increment usually occur [54]. In spite of this short period, the caries increment was significantly lower in the intervention group than in the control group. Felden et al. [36] and their study from Brazil, had a follow-up period of 3 years. When children were 4 years old, they evaluated the long-term effectiveness of a nutritional program given to mothers during the first year of the child's life. As both caries incidence and severity of caries was a less problem in the intervention group than in the control group, the program was found to be effective.

\section{Conclusions}

On the basis of this review, we maintain that in addition to studies of water fluoridation and fluoride toothpaste, there are other preventive intervention studies providing scientific evidence for caries reduction among children and adolescents with immigrant or low socioeconomic backgrounds. Supervised toothbrushing for 5-year-olds in schools was found to be an effective prevention technique for use in underprivileged groups, but also studies with a child/mother approach from very early, targeting nutrition and broad oral health education of mothers. For older children, a slow-release fluoride device and application of an APF gel have been shown to be effective.

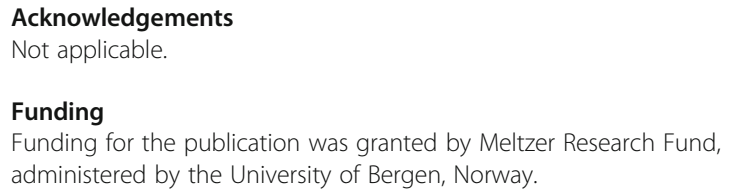

Availability of data and materials

The data supporting the findings are within the articles as references in the reference list.

\section{Authors' contributions}

Both authors (MSS and KSK) independently read and assessed the abstracts and selected articles in full text in this systematic review. MSS: contributed substantially to the manuscript writing. KSK: actively provided valuable comments. Both authors have read and approved the final manuscript.

\section{Ethics approval and consent to participate} Not applicable.

\section{Competing interests}

The authors declare that they have no competing interests. There are no financial completing interests as we have not received any grants. 


\section{Publisher's Note}

Springer Nature remains neutral with regard to jurisdictional claims in published maps and institutional affiliations.

Received: 2 March 2017 Accepted: 24 January 2018

Published online: 07 February 2018

\section{References}

1. Conway DI, Quarrell I, DR MC, Gilmour H, Bedi R, Macpherson LM. Dental caries in 5-year-old children attending multi-ethnic schools in greater Glasgow - the impact of ethnic background and levels of deprivation. Community Dent Health. 2007;24:161-5.

2. Baggio S, Abarca M, Bodenmann P, Gehri M, Madrid C. Early childhood caries in Switzerland: a marker of social inequalities. BMC Oral Health. 2015; 15:82.

3. Stecksen-Blicks C, Hasslof P, Kieri C, Widman K. Caries and background factors in Swedish 4-year-old children with special reference to immigrant status. Acta Odontol Scand. 2014;14:1-7.

4. Santamaria RM, Basner R, Schuler E, Splieth $\mathrm{CH}$. Inequalities in dental caries experience among 6-year-old German children after the caries decline. Acta Odontol Scand. 2015;73:285-91.

5. The National Board of Health and Welfare (Socialstyrelsen) Sweden. Socia differences in dental health among children and adolescents. Substrate report for health and care of children and adolescents [Sociala skillnader i tändhälsa bland barn och unga. Underlagsrapport till barns och ungas hälsa, vård och omsorg]. 2013. No 2013-5-34. ISBN: 978-91-7555-042-8.

6. Watson MR, Horowitz AM, Garcia I, Canto MT. A community participatory oral health promotion program in an inner-city Latino community. J Public Health Dent. 2001;61:34-41.

7. Brown L, Wall TP, Lazar V. Trends in untreated caries in primary teeth of children 2 to 10 years old. J Am Dent Assoc. 2000;131:93-100.

8. Christensen LB, Twetman S, Sundby A. Oral health in children and adolescents with different socio-cultural and socio-economic backgrounds. Acta Odontol Scand. 2010;68:34-42

9. Jacobsson B, Koch G, Magnusson T, Hugoson A. Oral health in young individuals with foreign and Swedish backgrounds -a ten-year perspective. Eur Arch Paediatr Dent. 2011;12:151-8.

10. Skeie MS, Espelid I, Skaare AB, Gimmestad A. Caries patterns in an urban preschool population in Norway. Eur J Paediatr Dent. 2005;6:16-22.

11. Sengupta N, Nanavati S, Cericola M, Simon L. Oral health integration into a pediatric practice and coordination of referrals to a Colocated dental home at a federally qualified health center. Am. Aust J Public Health. 2017:e1-3. https://doi.org/10.2105/AJPH.2017.303984.

12. Ludwig AF, Cox P, Ellahi B. Social and cultural construction of obesity among Pakistani Muslim women in north West England. Publ Health Nutr. 2011;14:1842-50.

13. Sisson KL. Theoretical explanations for social inequalities in oral health. Community Dent Oral Epidemiol. 2007;35:81-8.

14. Skeie MS, Klock KS, Haugejorden O, Riordan PJ, Espelid I. Tracking of parents' attitudes to their children's oral health-related behavior-Oslo, Norway, 2002-04. Acta Odontol Scand. 2010;68:49-56.

15. Bedi R, Elton RA. Dental caries experience and oral cleanliness of Asian and white Caucasian children aged 5 and 6 years attending primary schools in Glasgow and Trafford, UK. Community Dent Health. 1991:8:17-23.

16. de Hoog ML, Kleinman KP, Gillman MW, Vrijkotte TG, van Eijsden M, Taveras EM. Racial/ethnic and immigrant differences in early childhood diet quality. Public Health Nutr. 2014;17:1308-17.

17. Gregory J, Lowe S. National Diet and nutrition survey: young people aged 4 to 18. London: HMSO; 2000.

18. Pine CM, McGoldrick PM, Burnside G, Curnow MM, Chesters RK, Nicholson J, et al. An intervention programme to establish regular toothbrushing: understanding parents' beliefs and motivating children. Int Dent J. 2000; 50(Suppl):312-23.

19. Vargas CM, Ronzio CR. Disparities in early childhood caries. BMC Oral Health. 2006;6 Suppl 1:S3.

20. Petersen PE. The world oral health report 2003: continuous improvement of oral health in the 21st century-the approach of the WHO global oral health Programme. Community Dent Oral Epidemiol. 2003;31(Suppl 1):3-23.

21. Watt RG. Strategies and approaches in oral disease prevention and health promotion. Bull World Health Organ. 2005;83:711-8.
22. Gao XL, McGrath C. A review on the oral health impacts of acculturation. J Immigr Minor Health. 2011;13:202-13.

23. Adair PM, Pine CM, Burnside G, Nicoll AD, Gillett A, Anwar $S$, et al. Familial and cultural perceptions and beliefs of oral hygiene and dietary practices among ethnically and socio-economicall diverse groups. Community Dent Health. 2004;211(Suppl 1):102-11.

24. Schou $L$, Wight $C$. Does dental health education affect inequalities in dental health? Community Dent Health. 1994;11:97-100.

25. Sheiham A, Watt RG. The common risk factor approach: a rational basis for promoting oral health. Community Dent Oral Epidemiol. 2000;28:399-406.

26. Ammari JB, Baqain ZH, Ashley PF. Effects of programs for prevention of early childhood caries. A systematic review. Medical principles and practice : international journal of the Kuwait University, Health Science Centre. 2007;16:437-42.

27. Chen M. Oral health of disadvantaged populations. In: Cohen LK, Gift HC, editors. Disease prevention and oral health promotion: socio-dental sciences in action. Copenhagen: Munksgaard; 1995. p. 153-212.

28. Liberati A, Altman DG, Tetzlaff J, Mulrow C, Gotzsche PC, loannidis JP, et al The PRISMA statement for reporting systematic reviews and meta-analyses of studies that evaluate health care interventions: explanation and elaboration. J Clin Epidemiol. 2009;62:e1-34. https://doi.org/10.1016/j. jclinepi.2009.06.006.

29. WHO. Fluorides and oral health. Technical report series no. 846. Geneva: World Health Organization; 1994.

30. Iheozor-Ejiofor Z, Worthington HV, Walsh T, O'Malley L, Clarkson JE, Macey R, et al. Water fluoridation for the prevention of dental caries. The Cochrane Database Syst Rev. 2015;18:CD010856. https://doi.org/10.1002/14651858. CD010856.pub2.

31. Caries prevention. A systematic literature review. SBU-the Swedish council on technology assessment in health care. Göteborg: Elanders Graphic Systems; 2002.

32. Marinho VC, Higgins JP, Sheiham A, Logan S. Fluoride toothpastes for preventing dental caries in children and adolescents. The Cochrane Database Syst Rev. 2003;1:CD002278.

33. Harris RP, Helfand M, Woolf SH, Lohr KN, Mulrow CD, Teutsch SM, et al. Current methods of the US preventive services task force: a review of the process. Am J Prev Med. 2001;20(3 Suppl 3):21-35.

34. Guyatt GH, Oxman AD, Vist GE, Kunz R, Falck-Ytter Y, Alonso-Coello P, et al. GRADE: an emerging consensus on rating quality of evidence and strength of recommendations. BMJ. 2008 Apr 26;336:924-6.

35. Tutak M, Smektala T, Schneider K, Golebiewska E, Sporniak-Tutak K. Short dental implants in reduced alveolar bone height: a review of the literature. Med Sci Monit. 2013;19:1037-42.

36. Feldens CA, Giugliani ER, Duncan BB, Drachler Mde L, Vitolo MR. Long-term effectiveness of a nutritional program in reducing early childhood caries: a randomized trial. Community Dent Oral Epidemiol. 2010;38:324-32.

37. Mohebbi SZ, Virtanen JI, Vahid-Golpayegani M, Vehkalahti MM. A cluster randomised trial of effectiveness of educational intervention in primary health care on early childhood caries. Caries Res. 2009;43:110-8.

38. Curnow MM, Pine CM, Burnside G, Nicholson JA, Chesters RK, Huntington E. A randomised controlled trial of the efficacy of supervised toothbrushing in high-caries-risk children. Caries Res. 2002;36:294-300.

39. Jackson RJ, Newman HN, Smart GJ, Stokes E, Hogan Jl, Brown C, et al. The effects of a supervised toothbrushing programme on the caries increment of primary school children, initially aged 5-6 years. Caries Res. 2005;39:108-15.

40. Agrawal N, Pushpanjali K. Feasibility of including APF gel application in a school oral health promotion program as a caries-preventive agent: a community intervention trial. J Oral Sci. 2011;53:185-91.

41. Toumba KJ, Curzon ME. A clinical trial of a slow-releasing fluoride device in children. Caries Res. 2005:39:195-200.

42. Bravo M, Baca P, Llodra JC, Osorio E. A 24-month study comparing sealant and fluoride varnish in caries reduction on different permanent first molar surfaces. J Publ health. dent. 1997:57:184-6.

43. Armfield JM, Spencer AJ. Community effectiveness of fissure sealants and the effect of fluoridated water consumption. Community Dent Health. 2007:24:4-11.

44. Stokes E, Ashcroft A, Burnside G, Mohindra T, Pine CM. Randomised controlled trial of the efficacy of a high-fluoride gel self-applied by toothbrushing in children at high caries risk. Caries Res. 2011;45:475-85.

45. Khan KS, Kunz R, Kleijnen J, Antes G. Five steps to conducting a systematic review. J R Soc of Med. 2003;96:118-21.

46. Twetman S, Dhar $\mathrm{V}$. Evidence of effectiveness of current therapies to prevent and treat early childhood caries. Pediatr Dent. 2015;37:246-53. 
47. Harris R, Nicoll AD, Adair PM, Pine CM. Risk factors for dental caries in young children: a systematic review of the literature. Community Dent Health. 2004;21(1 Suppl):71-85

48. Grimes DA, Schulz KF. An overview of clinical research: the lay of the land. Lancet. 2002;359(9300):57-61.

49. Anderson M, Stecksen-Blicks C, Stenlund H, Ranggard L, Tsilingaridis G, Mejare I. Detection of approximal caries in 5-year-old Swedish children. Caries Res. 2005;39:92-9.

50. Twetman S, Axelsson S, Dahlen G, Espelid I, Mejare I, Norlund A, et al. Adjunct methods for caries detection: a systematic review of literature. Acta Odontol Scand. 2013;71:388-97.

51. O'Keefe EJ, AD MM, Jones CM, Curnow MM, Macpherson LM. Evaluation of dental therapists undertaking dental examinations in a school setting in Scotland. Community Dent Oral Epidemiol. 2016;44:515-22.

52. Macpherson LMD, Anopa Y, Conway DI, McMahon AD. National supervised toothbrushing program and dental decay in Scotland. J Dent Res. 2013;92: 109-13.

53. Gussy MG, Waters EG, Walsh O, Kilpatrick NM. Early childhood caries: current evidence for aetiology and prevention. J Paediatr Child Health. 2006:42:37-43.

54. Kay EJ, Locker D. Is dental health education effective? A systematic review of current evidence. Community Dent Oral Epidemiol. 1996;24:231-5.

55. Mejare IA, Klingberg G, Mowafi FK, Stecksen-Blicks C, Twetman SH, Tranaeus $\mathrm{SH}$. A systematic map of systematic reviews in pediatric dentistry-what do we really know? PLoS One. 2015;10:e0117537.

56. Meyer-Lueckel H, Grundmann E, Stang A. Effects of fluoride tablets on caries and fluorosis occurrence among 6- to 9-year olds using fluoridated salt. Community Dent Oral Epidemiol. 2010;38:315-23.

57. Oliveira BH, Salazar M, Carvalho DM, Falcao A, Campos K, Nadanovsky P. Biannual fluoride varnish applications and caries incidence in preschoolers: a 24-month follow-up randomized placebo-controlled clinical trial. Caries Res. 2014;48:228-36.

58. Pitchika V, Kokel CJ, Andreeva J, Crispin A, Hickel R, Kuhnisch J, et al. Effectiveness of a new fluoride varnish for caries prevention in pre-school children. J Clin Pediatr Dent. 2013:38:7-12.

59. Schuller AA, Kalsbeek $\mathrm{H}$. Effect of the routine professional application of topical fluoride on caries and treatment experience in adolescents of low socio-economic status in the Netherlands. Caries Res. 2003;37:172-7.

60. Riley JC, Klause BK, Manning CJ, Davies GM, Graham J, Worthington HV. Milk fluoridation: a comparison of dental health in two school communities in England. Community Dent Health. 2005;22:141-5.

61. Levin KA, Jones CM, Wight C, Valentine C, Topping GV, Naysmith R. Fluoride rinsing and dental health inequalities in 11-year-old children: an evaluation of a supervised school-based fluoride rinsing programme in Edinburgh. Community Dent Oral Epidemiol. 2009;37:19-26.

62. Wennhall I, Hajem S, Ilros S, Ridell K, Ekstrand KR, Twetman S. Fluoridated salt for caries prevention and control - a 2-year field study in a disadvantaged community. Int J Paediatr Dent. 2014:24:161-7.

63. Minah G, Lin C, Coors S, Rambob I, Tinanoff N, Grossman LK. Evaluation of an early childhood caries prevention program at an urban pediatric clinic. Pediatr Dent. 2008;30:499-504.

64. Songpaisan $Y$, Bratthall D, Phantumvanit $P$, Somridhivej $Y$. Effects of glass ionomer cement, resin-b ased pit and fissure sealant and HF applications on occlusal caries in a developing country field trial. Community Dent Oral Epidemiol. 1995;23:25-9.

65. Wennhall I, Matsson L, Schroder U, Twetman S. Outcome of an oral health outreach programme for preschool children in a low socioeconomic multicultural area. Int J Paediatr Dent. 2008;18:84-90.

66. Wagner $Y$, Greiner S, Heinrich-Weltzien R. Evaluation of an oral health promotion program at the time of birth on dental caries in 5-year-old children in Vorarlberg, Austria. Community Dent Oral Epidemiol. 2014;42:160-9.

67. Dulgergil CT, Ercan E, Yildirim I. A combined application of ART-fluoride varnish for immigrant junior field-workers: 12-months follow-up field trial in rural Anatolia. Oral Health Prev Dent. 2005;3:97-104.

68. Meurman P, Pienihakkinen K, Eriksson AL, Alanen P. Oral health programme for preschool children: a prospective, controlled study. Int J Paediatr Dent. 2009:19:263-73.

69. Blair Y, Macpherson LM, McCall DR, McMahon AD, Stephen KW. Glasgow nursery-based caries experience, before and after a community development-based oral health programme's implementation. Community Dent Health. 2004:21:291-8.
70. Blair Y, Macpherson L, McCall D, McMahon A. Dental health of 5-year-olds following community-based oral health promotion in Glasgow, UK. Int J Paediatr Dent. 2006;16:388-98.

71. Lindgard M. Early caries prevention for 2-year-olds in a socially exposed area. results after 1 year [Tidlig kariesprevention för två-åringar i ett socialt utsatt område. Resultat efter 1 år]. Tandhygienist Tidningen. 2013;Årgang 33. Nr 4.

72. Baca P, Munoz MJ, Bravo M, Junco P, Baca AP. Effectiveness of chlorhexidine-thymol varnish in preventing caries lesions in primary molars. J Dent Child (Chic). 2004:71:61-5.

73. Muller-Bolla M, Lupi-Pegurier L, Bardakjian H, Velly AM. Effectiveness of school-based dental sealant programs among children from low-income backgrounds in France: a pragmatic randomized clinical trial. Community Dent Oral Epidemiol. 2013:41:232-41.

74. Tickle M, Yeung CA, Milsom KM, Blinkhorn AS. The prescription and outcomes of fissure sealants applied to a group of high caries risk children by general dental practitioners working in the north west of England. Community Dent Health. 2007:24:135-9.

75. Baldini V, Tagkiaferri E, Ambrosano G, Meneghim M, Pereira A. Use of occlusal sealant in a community program and caries incidence in high- and low-risk children. J Appl Oral Sci. 2010:26:396-402.

76. Freeman R, Oliver M, Bunting G, Kirk J, Saunderson W. Addressing children's oral health inequalities in Northern Ireland: a research-practice-community partnership initiative. Public Health Rep. 2001;116:617-25

77. Chaffee BW, Feldens CA, Vitolo MR. Cluster-randomized trial of infant nutrition training for caries prevention. J Dent Res. 2013;92(7 Suppl):29S-36S.

78. Ismail Al, Ondersma S, Jedele JM, Little RJ, Lepkowski JM. Evaluation of a brief tailored motivational intervention to prevent early childhood caries. Community Dent Oral Epidemiol. 2011;39:433-48.

79. Kressin NR, Nunn ME, Singh $H$, Orner MB, Pbert $L$, Hayes $C$, et al. Pediatric clinicians can help reduce rates of early childhood caries: effects of a practice based intervention. Med Care. 2009:47:1121-8.

80. Kowash MB, Pinfield A, Smith J, Curzon ME. Effectiveness on oral health of a long-term health education programme for mothers with young children. Br Dent J. 2000;188:201-5.

81. van Palenstein Helderman WH, Munck L, Mushendwa S, van'et Hof MA, Mrema FG. Effect evaluation of an oral health education programme in primary schools in Tanzania. Community Dent Oral Epidemiol. 1997:25:296-300.

82. Plonka KA, Pukallus ML, Holcombe TF, Barnett AG, Walsh LJ, Seow WK. Randomized controlled trial: a randomized controlled clinical trial comparing a remineralizing paste with an antibacterial gel to prevent early childhood caries. Pediatr Dent. 2013:35:8-12

\section{Submit your next manuscript to BioMed Central and we will help you at every step:}

- We accept pre-submission inquiries

- Our selector tool helps you to find the most relevant journal

- We provide round the clock customer support

- Convenient online submission

- Thorough peer review

- Inclusion in PubMed and all major indexing services

- Maximum visibility for your research

Submit your manuscript at www.biomedcentral.com/submit 